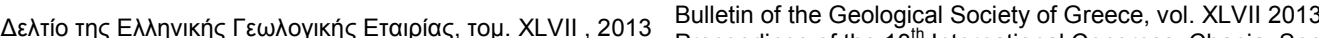
Proceedings of the $13^{\text {th }}$ International Congress, Chania, Sept.

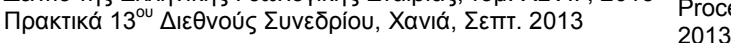

\title{
ASSESSMENT OF GROUNDWATER POLLUTION IN RELATION TO HEAVY METALS OF THE ALLUVIAL AQUIFER OF THRIASION PLAIN (NW ATTICA)
}

\author{
Kyriazis D. ${ }^{1}$, Zagana E. ${ }^{2}$, Stamatis G. ${ }^{1}$, Fillippidis F. ${ }^{1}$ and Psomiadis ${ }^{1}$. \\ ${ }^{1}$ Institute of Mineralogy-Geology, Agricultural University of Athens, Iera Odos 75, GR 11855 \\ Athens,Greece,stamatis@aua.gr,dskiriazis@yahoo.com,,filippidis_fil@hotmail.com, \\ mpsomiadis@aua.gr \\ ${ }^{2}$ Institute of Hydrogeology, Department of Geology, University of Patras, GR 26110, Rio-Patras, \\ Greece, e-mail: zagana@upatras.gr
}

\begin{abstract}
In this study the hydrogeological and hydrochemical characteristics of Thriasion Plain are presented focusing mainly on the presence of heavy metals in the alluvial aquifer. Two main aquifer systems exist in the study area: a) the karst aquifer hosted in the karstified carbonate formations, which structure the bedrock and the margins of the alluvial basin and b) the phreatic aquifer within the Quaternary deposits of the Thriasion Plain.

Coastal and submarine groundwater discharges show the direct connection of the aquifers with the sea causing intense salinization in both aquifers. The phreatic aquifer is characterized by high levels of TDS (483 - 13,067 $\mathrm{mg} / \mathrm{l})$ and correspondingly high degree of hardness (15.7 to $165.7^{\circ} \mathrm{dH}$ ). High concentrations of $\mathrm{Na}^{+}, \mathrm{Cl}, \mathrm{SO}_{4}^{2-}, \mathrm{NO}_{3}^{-}, \mathrm{NH}_{4}^{+}$and $\mathrm{PO}_{4}^{3-}$ reflect the diverse anthropogenic influences on the aquifer. The strong presence of heavy metals, $\mathrm{Cd}, \mathrm{Cu}, \mathrm{Fe}, \mathrm{Mn}, \mathrm{Ni}, \mathrm{Pb}, \mathrm{Sr}$ and $\mathrm{Zn}$ has been determined in the most of the samples. Their origin is associated with geogenic factors, such as the occurrences of bauxites, oxides derived from the alteration of rocks, especially shischts, organic matter within the Plio-Pleistocene sediments of the region, as well as with intense pressures from anthropogenic activities. In some cases the groundwater is improper not only for human consumption but also for many other uses.
\end{abstract}

Key words: Hydrochemistry, heavy metals, phreatic aquifer, Thriasion Plain.

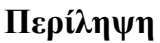

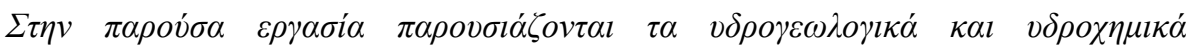

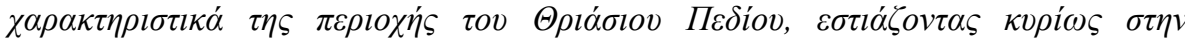

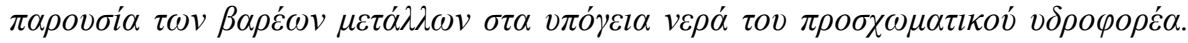

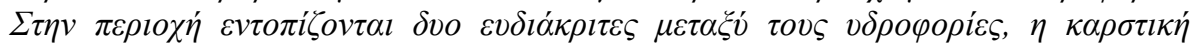

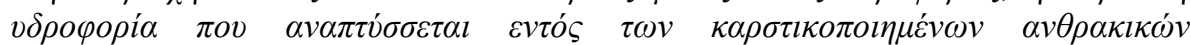

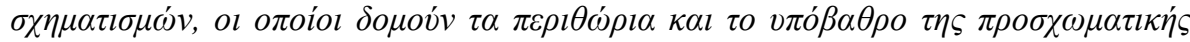

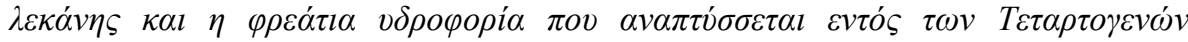

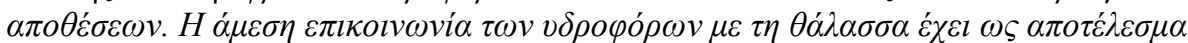

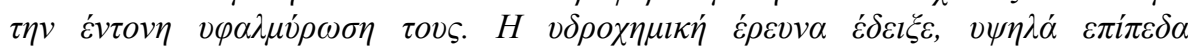

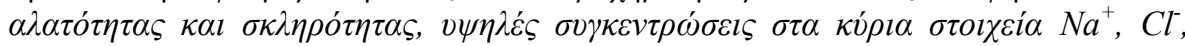




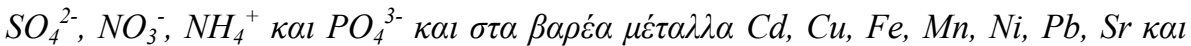

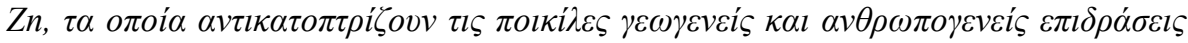

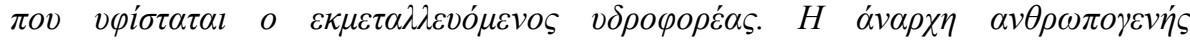

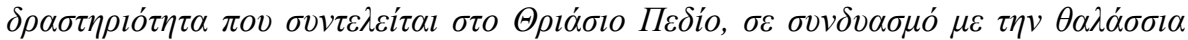

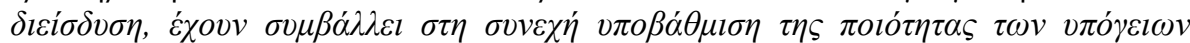

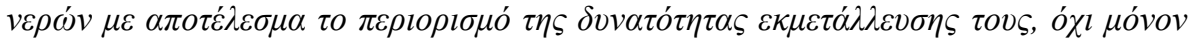

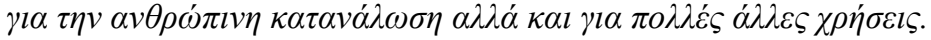

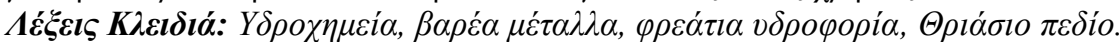

\title{
1. Introduction
}

Thriasion plain is an area characterized by several and intense human activities. Along the coastal zone and in the central part of the area intense building activity takes place, while in the north part the cultivation of vegetables prevails. The uncontrolled installation of various crafts and large industrial units, the operation of the military airport, the dense network of roads with the traffic of heavy vehicles are some features of the area. In recent decades the increased industrial activity has imposed significant environmental pressures in Thriasion Plain. These continual changes in land use, from cultivated land and pastures to industrial use, were not accompanied by the necessary infrastructures and implement measures (sewage treatment, biological waste water treatment, etc.) causing air, soil and groundwater pollution.

Soil studies, which have been conducted in the area of Thriasion plain, have recorded high loads of heavy metals in soil horizons resulting in surface- and groundwater pollution by mobilizing them (Massas et al., 2013). Previous hydrogeological investigations in the study area have shown intense salinization of groundwater, in both coastal and inland region, where the front of seawater intrusion is detected in about $8.5 \mathrm{~km}$ away from the coast. At the same distance from the coast is also detected the high pollutant load that characterizes the alluvial aquifer due to various anthropogenic pressures (Kuna et al., 1991; Karavitis et al., 2001, Paraschoudis 2002; Lioni et al., 2008, Iliopoulos et al., 2011, Christides et al., 2011). In this paper the results of a hydrogeochemical study conducted in Thriasion plain are presented. The purposes of the study were the investigation of the general groundwater quality, the evolution of the degradation of the groundwater quality from human activities (urban waste, agriculture, livestock, industry, etc.), emphasizing in the presence of heavy metals, as well as the determination of the suitability of water for various uses.

\section{Study Area}

The study area is located in the northwestern part of Attica (Figure 1). The mountains in the eastern, northern and western part form the relief of the area. The Aigaleo Mt (453m) at the southeastern delimits Thriasion plain from Attica basin. Parnitha Mt. (700m) and Patera Mt $(450 \mathrm{~m})$ defines Thriasion Plain to the east and north and to the west respectively, while in the south the study area is surrounding by Saronic Gulf. Low altitudes, from 0 to $100 \mathrm{~m}$, dominate in the lowland area of Thriasion plain, which is a paleo-karstic depression older than Quaternary of age. It presents a semicircular shape. During Quaternary it has been filled with fluvial and lacustrine deposits with thickness up to $200 \mathrm{~m}$. Low limestone hills outcrop locally in this region. These could be defined as "residual hills" characteristic for the advanced stage of the kartsification of the area.

Geology: The study area belongs geotectonically to Pelagonian Zone and is built up by alpine and post - alpine formations. Alpine formations consist of Triassic-Jurassic dolomitic limestones and limestones of Cretaceous age. The dolomitic limestones consist of thick bedded up to imbedded often dolomitized limestones fragmented, fractured and intensely karstified with a variable thickness of approx 300-700 m. They occur in the eastern, northern and northwestern part of the 
region covering most of its surface. The low part of Cretaceous limestones are thin bedded, locally marly, with a thickness of approx. $100 \mathrm{~m}$ and of Kenomanian age, while the middle part are thick bedded (Touronian age), with intense smell of bitumen and a thickness of approx $80 \mathrm{~m}$. Finally the upper part consists of thin bedded limestones that underlie the flysch formation with a thickness of $40 \mathrm{~m}$ (Senonian age). They occur mainly at the northwestern of Thriasion Plain and at places in the northwestern part of the plain.

The post alpine deposits consist of semi-consolidated Neogene formations and unconsolidated Quaternary deposits. The Neogene formations in the eastern part of Thriasion plain consist at their low parts of alternating layers of lacustrine mainly marls, clays and sandstones, while the upper parts are continental deposits mainly conglomerates and red mud. The Quaternary deposits consist of old Pleistocene and Holocene alluvial deposits.

The Pleistocene sediments covering the northern part of Thriasion Field with a significant thickness of $100 \mathrm{~m}$ are mostly torrential deposits, pebbles, gravel and sands of various origins. They usually occur with strong diagenesis as breccia-conglomerates including irregular intercalations of sand clays with calcareous debris. The Holocene sediments developed mainly in the coastal zone of Thriasion plain (Dounas et al., 1971; Katsikatsos et al., 1986) comprise clastic material, recent alluvial deposits and recent talus conus with a thickness of about 2 to $10 \mathrm{~m}$.

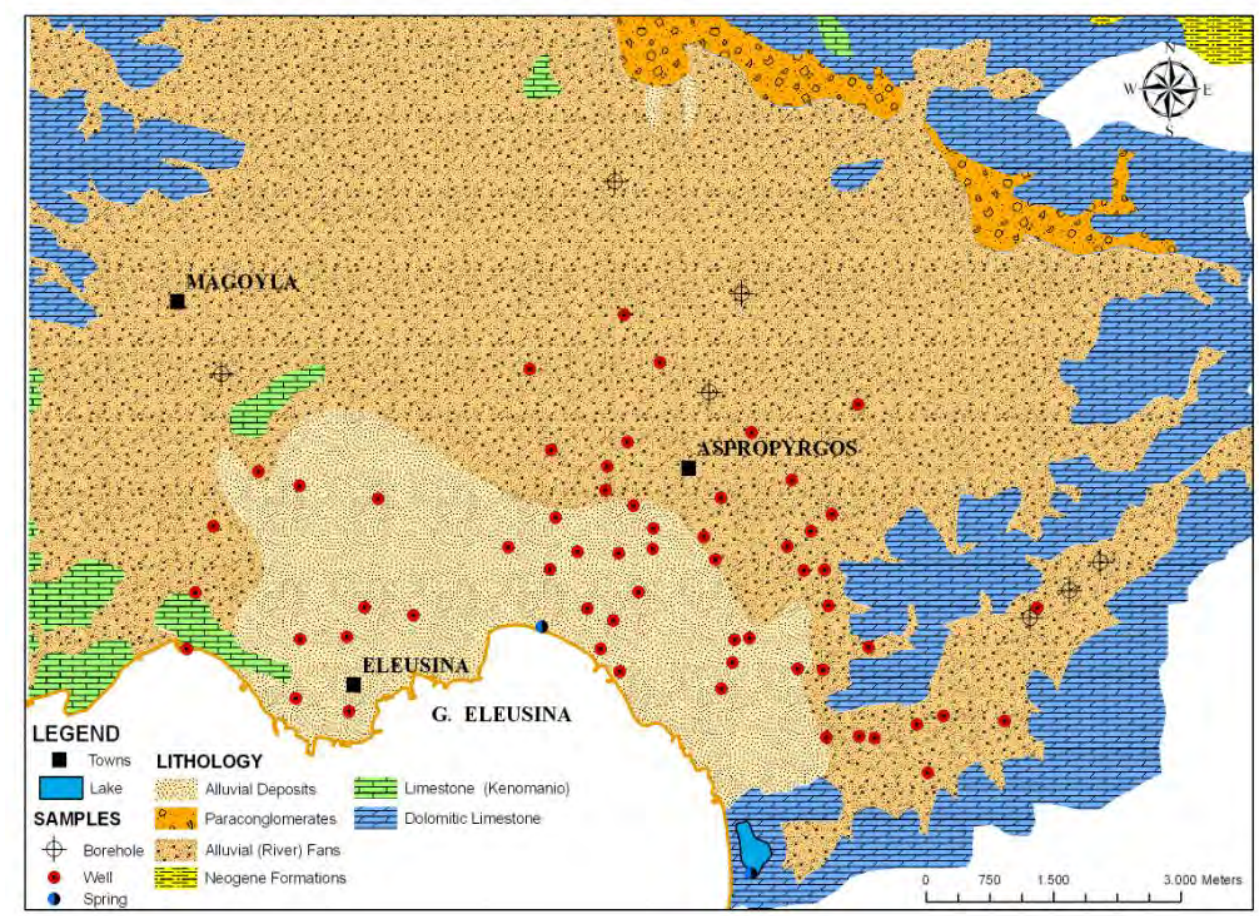

Figure 1 - Geological map of the study area (Digitized by IGME geological map 1:50 000, Sheet Athens to Eleusis (Katsikatsos et al. 1978)) and sampling points.

Hydrogeology: The climate of the study area is characterized as Mediterranean, semi-arid, with mild winters and hot summers. The average annual rainfall ranges between 300 and $400 \mathrm{~mm}$, with an average value of $390 \mathrm{~mm}$. The average annual temperature varies from $17^{\circ} \mathrm{C}$ and $19^{\circ} \mathrm{C}$. The carbonate formations, which occur in great extent in Thriasion plain, are intensely fragmented and karstified, due to the tectonic activity of the area. Within these formations a highly productive karst aquifer is developed. The average hydraulic conductivity is estimated to be $10^{-3} \mathrm{~m} / \mathrm{s}$ (Paraschoudis 2002). Paleozoic schist formations are the impermeable bedrock of the karst aquifer. 
Coastal and submarine springs at lower topographic places drain the karst aquifer. A significant amount of karst water discharges in Koumoundourou Lake located at the SE part, while another amount of the karst water flows towards the Eleusinian Gulf in the SW part of the plain. Finally karst water flows and feeds lateral the alluvial aquifer. Within the Quaternary deposits a significant aquifer is developed. It undergoes intense exploitation through wells and boreholes for drinking and irrigation purposes. The discharge rate of the wells is over $20 \mathrm{~m}^{3} / \mathrm{sec}$, while the discharge rate of the boreholes ranges from $100-150 \mathrm{~m}^{3} / \mathrm{h}$ (Kounis et al., 1991, Parasxoudis 2001). The hydraulic conductivity ranges between $10^{-2} \mathrm{~m} / \mathrm{s}$ and $10^{-4} \mathrm{~m} / \mathrm{s}$. The replenishment of the aquifer is realized by the infiltration of the rainwater, the infiltration of surface water, through the coarse sediment of its streambed as well as by the lateral feed of the karst system. In the coastal zone the aquifers adjoin the sea. Moreover the overexploitation of aquifer caused the decrease of the water level. Thus seawater intrusion phenomena occur resulting in the salinization of the groundwater.

\section{Hydrochemistry}

Material and Methods: During the wet period (December 2006) 51 samples from wells and 14 samples from boreholes were collected. The physicochemical parameters, temperature (T), electrical conductivity (EC) and $\mathrm{pH}$, were measured from untreated samples in-situ using the portable devices WTW/LF-330 for electrical conductivity and WTW/330i for $\mathrm{pH}$.

The samples were collected in two different types of polyethylene bottles $(100 \mathrm{ml}$ and $1000 \mathrm{ml}$ volume). The first bottle type of $100 \mathrm{ml}$ volume was filtered on site through $0.45 \mu \mathrm{m}$ pore size Millipore filters. It was then acidified to a pH about 2 with $65 \%$ ultra-pure $\mathrm{HNO}_{3}$ for heavy metals determination, $\mathrm{Cd}, \mathrm{Cu}, \mathrm{Fe}, \mathrm{Mn}, \mathrm{Ni}, \mathrm{Pb}, \mathrm{Sr}$ and $\mathrm{Zn}$ (Table 1). The second non-acidified aliquot (1 L volume) was retained to determine major cation analyses and non-metal ions $\left(\mathrm{Ca}^{2+}, \mathrm{Mg}^{2+}, \mathrm{Na}^{+}, \mathrm{K}^{+}\right.$, $\mathrm{HCO}_{3}^{-}, \mathrm{Cl}^{-}, \mathrm{SO}_{4}{ }^{2-} \mathrm{NO}_{3}{ }^{-}, \mathrm{NH}_{4}{ }^{+}$and $\mathrm{PO}_{4}{ }^{3-}$ ) (Table 1). Total Hardness, Calcium Hardness, Temporal Hardness as well as $\mathrm{Cl}^{-}$were determined with titration kits. The parameters $\mathrm{SO}_{4}{ }^{2-}, \mathrm{NO}_{3}{ }^{-}, \mathrm{NO}_{2}{ }^{-}$, $\mathrm{NH}_{4}{ }^{+}, \mathrm{PO}_{4}{ }^{3-}$ and $\mathrm{SiO}_{2}$ were determined by spectral photometry (HACH DR/3000) using the suitable $\mathrm{HACH}$ kits. The parameters $\mathrm{Ca}^{2+}, \mathrm{Mg}^{2+}, \mathrm{Sr}, \mathrm{Fe}, \mathrm{Mn}, \mathrm{Cu}, \mathrm{Cr}, \mathrm{Ni}, \mathrm{Pb}, \mathrm{Cd}$ and $\mathrm{Zn}$ were determined by atomic absorption spectroscopy (GBC/908AA), while $\mathrm{Na}^{+} \kappa \alpha \mathrm{K}^{+}$using Flamephotometer (INTECH/420). All the analyses were conducted at the laboratory of Mineralogy-Geology, Agriculture University of Athens.

Groundwater quality: The groundwater of the study area is characterized by a wide range of physicochemical parameters values. The water of the wells generally presents, except in certain cases, high concentrations of salts (TDS: $535-13,567 \mathrm{mg} / 1$ ), high hardness (TH: 14.6-165.7 ${ }^{0} \mathrm{dH}$ ), high salinization due to seawater intrusion $\left(\mathrm{Na}^{+}: 4.0-4045.9 \mathrm{mg} / 1, \mathrm{Cl}^{-}: 17.7-7269.7 \mathrm{mg} / 1\right.$ and $\mathrm{SO}_{4}{ }^{2-}$ : $8.2-782 \mathrm{mg} / \mathrm{l})$ and high concentrations of compounds of anthropogenic origin $\left(\mathrm{NO}_{3}{ }^{-}: 5.7-293 \mathrm{mg} / \mathrm{l}\right.$, $\mathrm{NH}_{4}{ }^{+}:$: 0.01-16.06 mg/l and $\left.\mathrm{PO}_{4}{ }^{3-}: 0.10-16 \mathrm{mg} / 1\right)$. The presence of all these elements and compounds reflects the geogenic and anthropogenic influences in the aquifer. The highest concentration is observed in the samples of the wells in the phreatic aquifer, which are located within the residential area, close to industrial units. In the most samples the concentrations exceed the upper allowable limits given by the Directive concerning the water quality for human use (EEC98/83 1998).

As is shown in Piper diagram (Figure 2) groundwater samples are classified mainly in three groups: i) In the first group belong the geo-alkaline waters with $\mathrm{Ca}-\mathrm{Mg}-\mathrm{HCO}_{3}$ and $\mathrm{Ca}-\mathrm{Mg}-\mathrm{Na}-$ $\mathrm{HCO}_{3}-\mathrm{Cl}-\mathrm{SO}_{4}$ hydrochemical types. ii) In the second group belong the brackish waters with Na$\mathrm{Cl}-\mathrm{HCO}_{3}$ and $\mathrm{Na}-\mathrm{Cl}$ hydrochemical types. They are mixed waters from sea water and karst water. iii) In the third group belong the water samples from wells and boreholes in the lowland of Thriasion plain, which present a geo-alkaline with high percentage of alkaline character. The hydrochemical types $\mathrm{Ca}-\mathrm{Mg}-\mathrm{Na}-\mathrm{HCO}_{3}, \mathrm{Ca}-\mathrm{Mg}-\mathrm{Na}-\mathrm{Cl}-\mathrm{HCO}_{3}$ and $\mathrm{Mg}-\mathrm{Na}-\mathrm{Cl}-\mathrm{SO}_{4}-\mathrm{HCO}_{3}$ prevail in this group, which exhibit seawater impacts. A small number of samples from boreholes present the 
hydrochemical types $\mathrm{Ca}-\mathrm{HCO}_{3}$ and $\mathrm{Ca}-\mathrm{Mg}-\mathrm{HCO}_{3}$ revealing the recharge of the area with fresh karst water.

As it shown in Durov diagram (Figure 3) cation - exchange processes $\left(\mathrm{Ca}-\mathrm{HCO}_{3}, \mathrm{Mg}-\mathrm{HCO}_{3}\right)$ and reverse cation - exchange processes $(\mathrm{Na}-\mathrm{Cl}, \mathrm{Mg}-\mathrm{Cl}$ and $\mathrm{Ca}-\mathrm{Cl})$ take place in the area, while a significant number of the samples undergo mixing from sea water and fresh groundwater.

Table 1 - Results of hydrochemical analyses.

\begin{tabular}{|c|c|c|c|c|c|c|}
\hline \multirow[t]{2}{*}{ Samples } & \multicolumn{3}{|c|}{51 Samples of wells } & \multicolumn{3}{|c|}{14 Samples of boreholes } \\
\hline & $\min$ & $\max$ & mean & $\min$ & Max & mean \\
\hline $\mathrm{Ta}{ }^{0} \mathrm{C}$ & 11.5 & 20.2 & 16.2 & 13.5 & 19.4 & 17.4 \\
\hline $\mathrm{EC} \mu \mathrm{S} / \mathrm{cm}$ & 674 & 23,100 & 3671 & 629 & 3780 & 1676 \\
\hline $\mathrm{pH}$ & 7.0 & 8.27 & 7.4 & 7.12 & 7.9 & 7.43 \\
\hline Tot. Hardness $\quad{ }^{0} \mathrm{dH}$ & 14.6 & 165.7 & 53.4 & 15.7 & 85.9 & 38.2 \\
\hline Temp. Hardness ${ }^{0} \mathrm{dH}$ & 11.7 & 41.3 & 24 & 15.4 & 31.1 & 20.6 \\
\hline Perm. Hardness ${ }^{0} \mathrm{dH}$ & 0.0 & 154 & 29.7 & 0.0 & 68.0 & 18.8 \\
\hline $\mathrm{mg} / \mathrm{l}$ & 49.6 & 584.8 & 189.8 & 61.6 & 272.0 & 135.4 \\
\hline $\mathrm{Mg}^{2+}$ & 10.6 & 421 & 115.7 & 26 & 286.3 & 85.4 \\
\hline $\mathrm{mg} / \mathrm{l}$ & 11.8 & 4045.9 & 412.5 & 29.6 & 540 & 129.4 \\
\hline $\mathrm{mg} / \mathrm{l}$ & 0.3 & 166 & 17.5 & 1.9 & 18 & 6.9 \\
\hline $\mathrm{HCO}_{3}^{-}$ & 256.2 & 899.7 & 523.9 & 335.5 & 677.1 & 440.3 \\
\hline $\mathrm{mg} / \mathrm{l}$ & 39.0 & 7269.5 & 821.4 & 17.7 & 939.7 & 346.8 \\
\hline $\mathrm{SO}_{4}{ }^{2-}$ & 22.8 & 782 & 232.8 & 8.2 & 268.7 & 94.2 \\
\hline $\mathrm{NO}_{3}^{-}$ & 5.7 & 293 & 91.3 & 12.8 & 239.3 & 93 \\
\hline $\mathrm{NH}_{4}^{+}$ & 0.01 & 16.06 & 2.85 & 0.55 & 4.30 & 1.74 \\
\hline $\mathrm{PO}_{4}^{-}$ & 0.1 & 1.14 & 0.35 & 0.12 & 1.05 & 0.3 \\
\hline $\mathrm{SiO}_{2}$ & 0.5 & 26.4 & 15.8 & 9.6 & 20.8 & 16.6 \\
\hline ppm & 0.027 & 0.064 & 0.046 & 0.028 & 0.072 & 0.049 \\
\hline ppm & 0.058 & 1.05 & 0.106 & 0.061 & 0.188 & 0.092 \\
\hline ppm & 0.001 & 0.636 & 0.154 & 0.001 & 0.279 & 0.138 \\
\hline ppm & 0.007 & 0.610 & 0.085 & 0.046 & 0.112 & 0.077 \\
\hline ppm & 0.001 & 0.282 & 0.111 & 0.001 & 0.300 & 0.125 \\
\hline ppm & 0.002 & 0.417 & 0.221 & 0.006 & 0.454 & 0.241 \\
\hline ppm & 0.613 & 4.016 & 2.281 & 0.689 & 2.370 & 1.925 \\
\hline ppm & 0.001 & 0.400 & 0.062 & 0.005 & 0.535 & 0.108 \\
\hline TDS & 535 & 13567 & 2423 & 770 & 2714 & 1353 \\
\hline
\end{tabular}




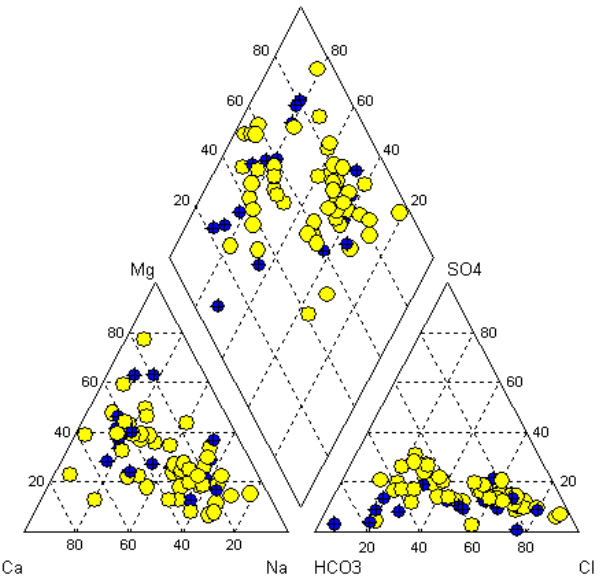

Figure 2 - Classification of groundwaters in the Piper diagram ( $O$ : wells. $\$$ : boreholes).

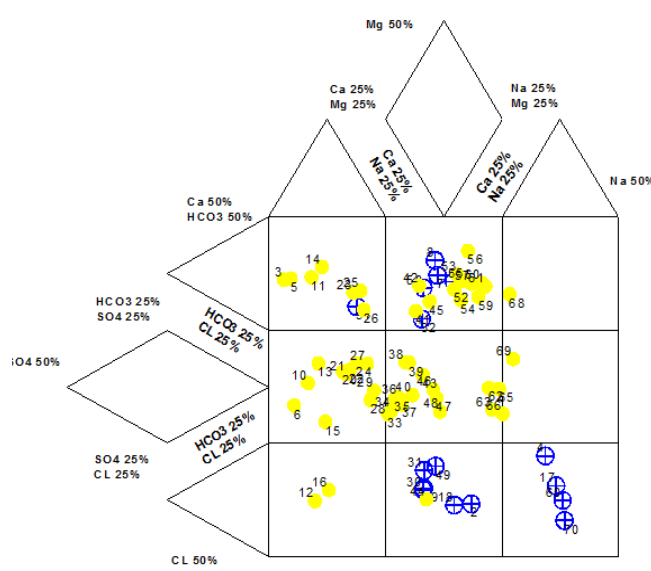

Figure 3 - Classification of groundwaters based on Durov diagram $(O$ : wells. boreholes).

Heavy metals: The groundwaters of the study area present high concentrations of the heavy metals $\mathrm{Cd}, \mathrm{Cu}, \mathrm{Fe}, \mathrm{Mn}, \mathrm{Ni}, \mathrm{Pb}, \mathrm{Sr}$ and $\mathrm{Zn}$. The concentration of $\mathrm{Fe}_{\mathrm{tot}}$ ranges from 0.001 to $0.636 \mathrm{ppm}$, while in $51 \%$ of the samples the concentration exceeds $0.2 \mathrm{ppm}$, the upper limit given by the Directive concerning the water quality for human use (EEC98/83 1998). Mn concentration varies between 0.007 and $0.610 \mathrm{ppm}$, while in $74 \%$ of the samples the concentration exceeds $0.05 \mathrm{ppm}$, the upper limit given by the Directive concerning the water quality for human consumption. Ni concentration varies between 0.001 and $0.29 \mathrm{ppm}$, while in $59 \%$ of the samples the concentration exceeds $0.02 \mathrm{ppm}$, the upper limit given by the European Directive. All the samples present $\mathrm{Cd}$ concentrations between $0.027-0.072 \mathrm{ppm}$ exceeding the upper limit of $0.005 \mathrm{ppm}$. The concentration of $\mathrm{Pb}$ ranges from $0.002-0.454 \mathrm{ppm}$, presenting in $95 \%$ of the samples values above the upper limit of $0.010 \mathrm{ppm}$. The concentrations of $\mathrm{Cu}$ and $\mathrm{Zn}$ range from $0.058-1.050 \mathrm{ppm}$ and $0.001-0.535 \mathrm{ppm}$ respectively and do not exceed the upper limits of $2.0 \mathrm{ppm}$ and $5.0 \mathrm{ppm}$ respectively (WHO 1993, EU-98/83 1998). The concentration of $\mathrm{Sr}$ is high and ranges from 0.613$4.016 \mathrm{ppm}$. It could be attributed to the disillusion of the minerals selestine $\left(\mathrm{SrSO}_{4}\right)$ and strontianite $\left(\mathrm{SrCO}_{3}\right)$ included in the sediments and evaporates. The highest concentration of the heavy metals is associated with geogenic factors, such as the occurrences of bauxites, oxides derived from the alteration of rocks and the organic matter within the unconsolidated sediments of the region, which is characterized for its ability to bind the heavy metals. Intense pressures from anthropogenic activities, such as air pollutants from traffic and gas industrial plants, the function of Eleusis military airport, industrial and municipal waste, waste dumps and agricultural crops could also contribute to the significant presence of heavy metals in the groundwaters of the area.

The spatial distribution of heavy metals is shown in Figure 4. The presence of Fe prevails in the west part of the area, while $\mathrm{Mn}, \mathrm{Ni}$ and $\mathrm{Zn}$ occur in the groundwaters in the east part of the area. This could be attributed to the presence of the landfill of Ano - Liosia located at the eastern margins of Thriasion plain. $\mathrm{Cd}, \mathrm{Cu}, \mathrm{Pb}$ and $\mathrm{Sr}$ present higher concentrations in the central and north part of the area. Their distribution is associated with both occurrences of bauxite in the north and west of Thriasion Field and the existence of distributed manufacturing units and the lack of waste water treatment facilities. 
$\mathrm{Fe}$

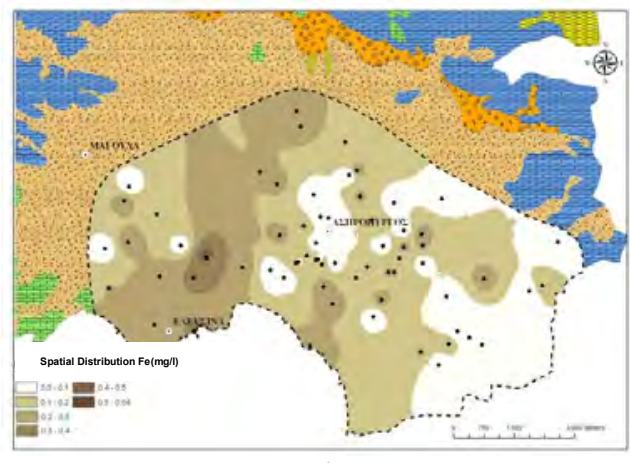

$\mathrm{Ni}$

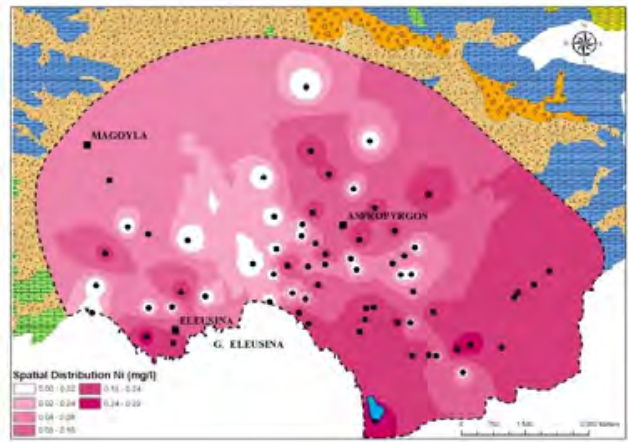

$\mathrm{Pb}$

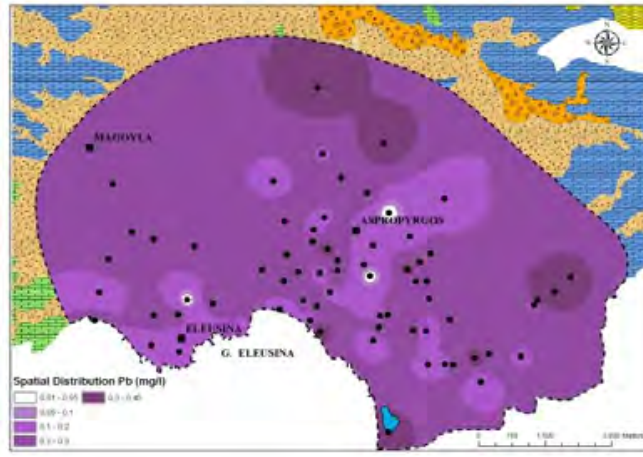

$\mathrm{Zn}$

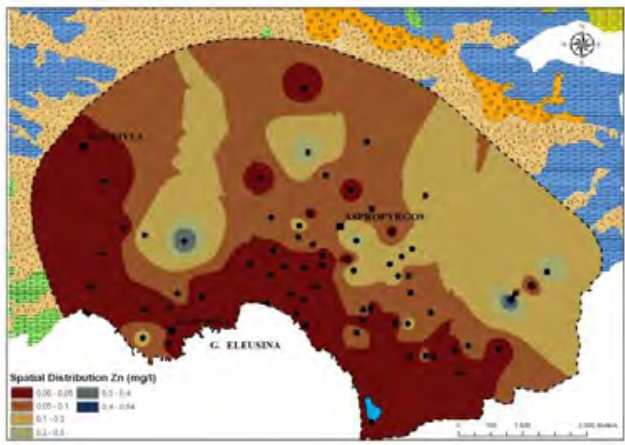

$\mathrm{Mn}$

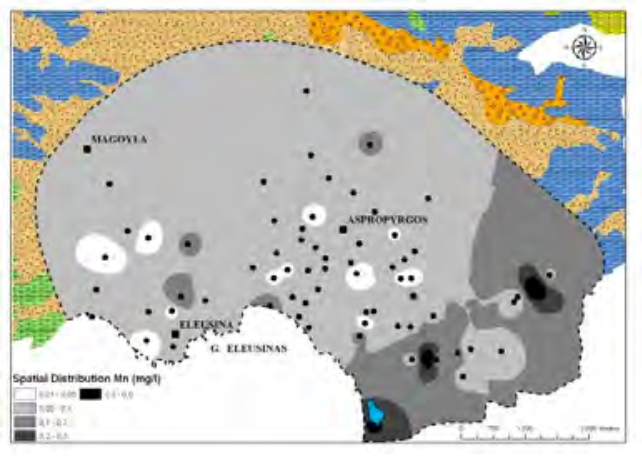

$\mathrm{Cd}$

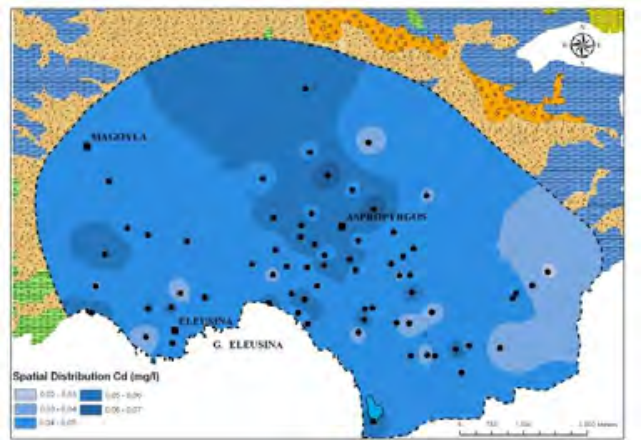

$\mathrm{Cu}$

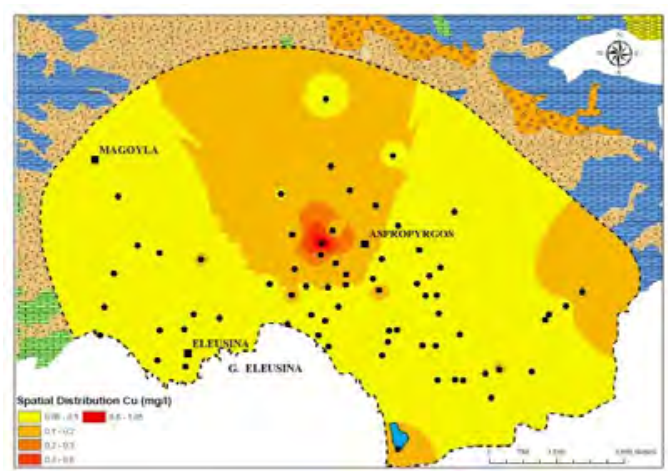

$\mathrm{Sr}$

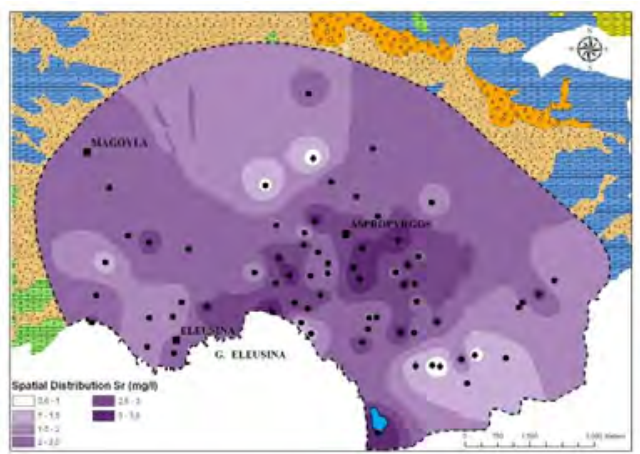

Figure 4 - Spatial distribution of heavy metals in groundwater at the Thriasio plain area. ( Fe, Mn, Cd, Pb, Ni, Cu, Zn and Sr). 
To detect relationships exist between the various elements and parameters, factor analysis is used with the statistical program SPSS. The method collects data into groups which are called factors. The load factors show how important is the participation of the respective variable factor (Davis 1986).

Table 2 - Results of factor analyses.

\begin{tabular}{|c|c|c|c|c|}
\hline Elements & Factor 1 & Factor 2 & Factor 3 & Factor 4 \\
\hline $\mathrm{Ca}$ & .230 & $\mathbf{. 7 6 8}$ & -.123 & -.129 \\
\hline $\mathrm{Mg}$ & $\mathbf{. 7 2 4}$ & .299 & -.276 & -.110 \\
\hline $\mathrm{Na}$ & $\mathbf{. 9 5 1}$ & .043 & .010 & .100 \\
\hline $\mathrm{K}$ & $\mathbf{. 8 9 4}$ & -.222 & .051 & .120 \\
\hline $\mathrm{Cl}$ & $\mathbf{. 9 5 3}$ & .140 & -.072 & -.003 \\
\hline $\mathrm{SO}_{4}$ & $\mathbf{. 8 6 6}$ & .307 & -.067 & .068 \\
\hline $\mathrm{NO}_{3}$ & -.234 & $\mathbf{. 7 9 4}$ & -.271 & .075 \\
\hline $\mathrm{Pb}$ & -.059 & .039 & .057 &. $\mathbf{7 6 0}$ \\
\hline $\mathrm{Zn}$ & -.139 & -.002 & .100 & -.691 \\
\hline $\mathrm{Ni}$ & -.092 & -.162 & $\mathbf{. 6 3 4}$ & -.049 \\
\hline $\mathrm{Mn}$ & .071 & -.098 & $\mathbf{. 6 8 9}$ & .231 \\
\hline $\mathrm{Sr}$ & .355 &. $\mathbf{7 3 1}$ & .060 & .139 \\
\hline $\mathrm{Cd}$ & .151 & -.035 & $\mathbf{- . 6 9 7}$ & .340 \\
\hline \% of $\mathbf{V a r i a n c e}$ & $\mathbf{3 2 . 2}$ & $\mathbf{1 5 . 7}$ & $\mathbf{1 2 . 0}$ & $\mathbf{1 0 . 1}$ \\
\hline
\end{tabular}

In Table 2 is shown that the first group, which accounts for $32.2 \%$ of the variance in the data matrix connecting the ions $\mathrm{Mg}^{2+}, \mathrm{Na}^{+}, \mathrm{K}^{+}, \mathrm{Cl}^{-}$and $\mathrm{SO}_{4}{ }^{2-}$. It represents the brackish waters resulting from the seawater intrusion in the aquifers of the study area. The second group accounts for $15.7 \%$ of the total variance, connecting elements $\mathrm{Ca}^{2+}, \mathrm{Sr}$ and $\mathrm{NO}_{3}{ }^{-}$. The coexistence of these shows the use of fertilizers. The relationship between nitrate and calcium could be explained as ion exchange relationship between the ion of ammonium resulting from the hydrolysis of ammonia fertilizer and calcium that is a component of carbonate minerals in the area. The coexistence of $\mathrm{Ca}^{2+}$ and $\mathrm{Sr}^{2+}$ is directly related to the chemical affinity of the two elements. The third and fourth groups accounts for $12 \%$ and $10.1 \%$ of the total variance, respectively. They connect the elements $\mathrm{Ni}, \mathrm{Mn}, \mathrm{Cd}, \mathrm{Pb}$ and $\mathrm{Zn}$ that could be associated with the dissolution of bauxites and various oxides and obviously with different anthropogenic impacts.

\section{Conclusions}

Two systems developed in the study area, the karst system that structures the east, north and west margins of the basin and the greatly expanded in size clastic system of Quaternary age. In the coastal zone where the contact of carbonate rocks with the sea is immediate, intense salinization of karst waters takes place. The high concentrations of the main elements and heavy metals reveal the degradation of the alluvial aquifer, which could be attributed to both natural factors and anthropogenic impacts. These concentrations values exceed the upper limits for human consumption and the majority of groundwater samples are characterized as inappropriate. This is attributed to geogenic factors and other anthropogenic impacts, as Thriasion plain undergoes intense environmental pressure from various human activities. 


\section{References}

Christides A., Mavrakis A. and Mitilineou A. 2011. A case of intense seawater intrusion to aquifer of the Thriasio Plain. Greece, Proceedings of the 12th International Conference on Environmental Science and Technology (12th ICEST). Vol B:152-159.

Davis J.C. 1986. Statistics and data analysis in geology, Wiley, New York.

Dounas A. 1971. The geology between Megara and Erithres area. PhD Thesis, University of Athens.

EU Council directive 98/83 1998. Council Directive 98/83/EC of the European Parliament on the quality of water intended for human consumption, The European Parliament and the Council of the European Union, Off J L 330.

Iliopoulos V., Stamatis G. and Stournaras G. 2011. Marine and human activity effects on the groundwater quality of Thriasio Plain, Attica, Greece, Advances in the Research of Aquatic Environment. Environmental Earth Sciences. 3. 409-416. DOI: 10.1007/978-3-642-24076$8-48$.

Karavitis C., Bosdogianni A. and Vlachos E. 2001. Environmental Management approaches and water resources in the stressed region of Thriassion, Greece, Global Nest: the Int. J. Vol 3. No 2. p. 131-144.

Katsikatsos G. et al 1986. Geological Map Athens-Eleusis 1:50.000. I.G.M.E.

Kounis G. and Siemos N. 1991. Spot hydrogeological investigation of the aquifers of Thriassio Plain for supply of Hellenic Petroleum Company, IGME.

Lioni A. Stournaras G. and Stamatis G. 2008. Degradation of Groundwater quality of Thriassio Plain through Natural Factors and human activity. Proceedings of the 8th Hydrogeological Congress of Greece. vol.2 p.577.

Massas I., Kalivas D., Ehaliotis C. and Gasparatos D. 2013. Total and available heavy metal concentrations in soils of the Thriassio Plain (Greece) and assessment of soil pollution indexes, Environ Monit Assess.

Paraschoudis B. 2002. Hydrogeological study of West Attica, Unpublished report, Ministry of Agriculture

WHO 1993. Guidelines for drinking water quality. vol.1. $2^{\text {nd }}$ ed. World Health Organization. Geneva. 